\title{
COMENTÁRIO EDITORIAL RESILIÊNCIA E RESISTIR À REJEIÇÃO PARA O SUCESSO NA CARREIRA
}

Um dos resultados possíveis do processo de submissão de um artigo para publicação é a rejeição. Embora este não seja, obviamente, o resultado desejável é importante entender o que isso significa e como proceder em seguida. Os que fizeram os seus doutorados em universidades norte-americanas ouviram a insistência com que os Professores falavam da necessidade de desenvolver uma "thick skin" - ou capacidade de reagir à rejeição e a comentários desfavoráveis. Assim, é importante dedicar um comentário editorial à rejeição e resiliência à rejeição.

A capacidade de reagir a rejeições, ou ter uma "thick skin" é, em minha opinião, um dos principais atributos que diferenciam os autores mais prolíficos. A rejeição não é fácil mas lembre-se o que que foi rejeitado foi um dos seus artigos, em apenas um periódico e por 2 ou 3 revisores. Não foi você e todo seu trabalho passado ou futuro, nem a sua capacidade de fazer boa pesquisa e bons trabalhos.

As rejeições fazem parte da profissão de pesquisador. Mas, a rejeição magoa no ego. Estou convicto que nenhum autor, professor pesquisador ou estudante, deseja receber rejeições de periódicos. No

\author{
Manuel Aníbal Silva Portugal Vasconcelos Ferreira \\ Editor Adjunto RIAE \\ Universidade Nove de Julho - UNINOVE \\ Programa de Pós-Graduação em Administração
}

entanto, uma rejeição não é motivo para total frustração e não é inédito que após receber uma rejeição e trabalhar na revisão do artigo se consiga uma publicação num periódico de maior reputação e impacto que aquele a que havia inicialmente submetido. Uma rejeição não é, assim, usualmente, uma indicação que não há salvação para o manuscrito. Mas, é sinal que há que melhorar e com a vantagem de já ter comentários e sugestões de avaliadores (referes) anónimos.

O que fazer em caso de rejeição? Após receber uma rejeição recomendo que siga as seguintes etapas. Primeira, leia os comentários dos revisores cuidadosamente, mas guarde-os e deixe de lado durante uns dias. Deixe passar a frustração antes de voltar a trabalhar em melhorar o manuscrito. Segunda, procure entender porque $\mathrm{o}$ artigo foi rejeitado. Analise as sugestões e as críticas e veja o que pode fazer e o que não pode. Identifique quais as limitações mais importantes e o que pode prejudicar a publicação do artigo. Terceira, analise, realisticamente, se artigo cumprirá os requisitos de outro periódico que possa ser mais adequado face ao conteúdo e método do artigo - 
caso não seja será preciso pensar cuidadamente como rever. Em muitos casos a rejeição deve-se a uma má seleção do periódico e o artigo não ser adequado ao tipo de artigos que publica, ao foco, aos métodos, etc. Para evitar isto, leia desfolhe o periódico antes de submeter e veja a sua missão. Ou seja, entenda o tipo de artigos que usualmente publica e os tópicos que cobre. A quarta etapa é não submeter o artigo imediatamente a outro periódico sem fazer alguma revisão substancial dos aspectos que conduziram à rejeição e sem verificar as orientações para os autores do novo periódico. O objetivo, após uma rejeição é melhorar para uma publicação futura, não resubmeter para nova rejeição. Na quinta, volta ao artigo e começa a assinalar o que precisa fazer e onde precisa fazer. Use, para isso, as sugestões dos revisores. Por exemplo, alterar o foco da revisão da literatura, refazer a análise estatística, aprofundar a discussão das limitações, assinalar mais enfaticamente a contribuição, etc. Ou seja, nesta etapa esta a organizar o trabalho. Por fim, reveja todo o manuscrito. Mas, a regra de ouro é: nem responder a uma rejeição no dia em que se recebe, nem resubmeter o manuscrito exatamente na sua forma original.

\section{O FENÔMENO DA REJEIÇÃO}

Identificar as taxas de aceitação, ou rejeição, dos diferentes periódicos não é tarefa simples. A maioria dos periódicos não disponibiliza essa informação. É possível ver alguma informação sobre os periódicos e respectivas taxas de rejeição no Cabell's Directory of Publishing Opportunities, mas o acesso não é gratuito. As taxas de aceitação são, também, disponibilizadas pela American Psychological Association (APA) em www.apa.org/pubs/journals/statistics.aspx. As taxas de aceitação variam muito com a classificação dos periódicos; sendo que, usualmente, os periódicos com menores taxas de aceitação são os mais prestigiados (Krueger e Shorter, 2011). Mas, importa notar que não há aqui uma relação de causa-e-efeito direta entre taxas de rejeição e impacto dos periódicos; o que há é que os periódicos com maior impacto são mais procurados e têm muito maior volume de submissões originando a que o editor e avaliadores tenham critérios mais estritos.

Lorraine Eden (2009), enquanto editora do Journal of International Business Studies, o mais reputado periódico em negócios internacionais, reportou que entre 2002 e 2008 o número de submissões havia duplicado, cerca de 43 por mês em média, e que a taxa de aceitação tinha baixado para cerca de $15 \%$. Os dados da American Psychological Association (APA), para 2012, apontam que alguns periódicos têm taxas de rejeição bastante altas, como, por exemplo: Journal of Applied Psychology (93\%), Journal of Personality and Social Psychology (88\%),
Psychological Review (85\%), Journal of Consumer Psychology (90\%), entre outros (fonte: http://www.apa.org/pubs/journals/statistics.aspx) mas não é incomum nas ciências sociais identificar taxas de rejeição similares. Assim, a rejeição, nestes periódicos é a norma e não a exceção.

Em Administração, Daniel Hamermesh, com dados de 2008, reportou taxas de aceitação extremamente baixas em alguns periódicos (taxas de aceitação entre parêntesis): American Economic Review (7\%), Econometrica (9\%), Journal of Political Economy (5\%), Quarterly Journal of Economics (4\%), Economica (11\%), Economics Letters (17\%), European Economic Review (9\%), RAND Journal of Economics (11\%), American Sociological Review (8\%), entre outros.

\section{OS PORQUÊS DA REJEIÇÃO}

Mas, porque os artigos são rejeitados? Quais as suas principais debilidades? Certamente que há múltiplos motivos possíveis para a rejeição. Uma parte crescente dos artigos são rejeitados logo pelo editor no desk review e apenas os restantes seguem no processo. Certamente, também, a avaliação pelos pares é subjetiva, pelo que em alguns casos podem ser questões de gosto, de interesse, de ponto de vista, que diferindo entre o autor e algum revisor conduz à rejeição. Uma escolha inadequada do periódico pode ser outro motivo. No entanto, a maioria das vezes podemos identificar algumas lacunas mais frequentes que, pelo menos, ajudam à rejeição. Enuncio em seguida algumas dessas lacunas mas saliento que o autor(es) deve procurar aproveitar os comentários dos revisores para melhorar o artigo e conseguir a publicação numa submissão futura.

As razões mais comuns para a rejeição:

- $\quad$ O artigo não se enquadra bem ao periódico (se o autor tivesse analisado a missão e o tipo de artigos publicados, teria evitado esta situação),

- $\mathrm{O}$ artigo ainda precisa de muito trabalho antes de poder ser efetivamente publicável (possivelmente o autor submeteu um artigo numa ase ainda muito inicial e ao qual ainda não dedicou tempo suficiente na revisão e melhoria),

- O autor não seguiu as normas (author guidelines) do periódico - ainda que este motivo, usualmente, não conduza a rejeição direta mas antes a uma solicitação para fazer o ajustamento, podendo ser subsequentemente resubmetido ao mesmo periódico,

- O artigo está pobremente escrito; o estilo e escrita é confuso, ambíguo, vago e sem um foco evidente,

- O artigo não tem uma questão de pesquisa explícita, ou se tem não lhe responde, 
- O artigo não contém um trabalho original; isto é, não tem contribuição, sendo apenas uma reprodução do que já tinha sido feito antes ainda que em outro contexto,

- O artigo não é explícito em mostrar qual a contribuição,

- O artigo ignora um conjunto de literatura recente que é relevante e pertinente para o seu foco específico,

- Não segue uma estrutura de organização padrão,

- As hipóteses, no caso de trabalho empírico, não estão fundamentadas numa racionalidade conceitual clara,

- Refere uma contribuição e implicações que efetivamente não inclui,

- $\quad$ artigo não tem rigor acadêmico, não usa estatísticas adequadas, a amostra é problemática, a unidade de análise é desajustada da componente conceitual (por exemplo, discute países mas mensura ao nível de empresas ou de indivíduos)

- Ou, simplesmente, e não é incomum, não é mesmo um artigo - pode ser um relatório, um texto interessante mas não cumpre os requisitos do pensamento científico.

Dada a importância que é dada à novidade nos artigos, ou à contribuição, na forma como trazem novo conhecimento e não serem apenas meras replicações de estudos existentes, a sugestão que usualmente dou aos meus alunos é que um artigo não é um conto de mistério do inspetor Hercule Poirot. A regra é ser claro e explícito logo no início do artigo sobre o que ele trata, qual a teoria, a metodologia, os principais resultados e, muito importante, qual a contribuição que apresenta. O revisor e o leitor querem saber imediatamente porque devem ler o artigo e o que ele trará de novo. Depois, é preciso garantir coerência pelo que sugiro que ao longo da escrita vá sempre voltando atrás e observando se o que afirmou no início sobre o que o artigo iria tratar se mantem, não perdendo o foco em cada uma das seções do artigo.

\section{DIMINUIR A PROBABILIDADE DE REJEIÇÃO}

Não tenho uma receita, nem um insight especial, para evitar a rejeição mas há um conjunto de indicações, de cuidados e práticas, para como diminuir a probabilidade de rejeição que podemos adotar. Ainda que estas dicas não sejam novas, a realidade é que muitas vezes acabamos por não as seguir. A primeira é que muitos dos problemas que se verificarão mais tarde nos artigos emergem de uma menos boa especificação logo na fase inicial de concepção da pesquisa. Assim, sugiro que peça a colegas e estudantes de doutorado que analisem e realmente critiquem a ideia, a teoria, a questão de pesquisa, os métodos, as variáveis e amostra. As críticas de revisores baseadas em questões metodológicas tendem a ser das mais difíceis de ultrapassar uma vez a pesquisa já realizada (veja Huff, 1998).

A segunda dica é que preste ainda mais atenção à escrita. $\mathrm{O}$ padrão de escrita para publicação internacional, e mesmo nacional, está a mudar rapidamente para um estilo simples, direto, na voz ativa, concisa, específica, com frases curtas e diretas e uma organização sequencial bem estruturada dos parágrafos (Huff, 1998; Booth, Colomb \& Williams, 2008). Não se pretende uma escrita académica, no sentido popular usado para evidenciar algo difícil de entender, com muito jargão técnico e pretensioso. Novamente, uma revisão amigável por um colega pode ser muito útil e importa notar que se o revisor amigável não entender algo ou tiver dúvidas, é provável que, quando submeter a um periódico, o revisor também não vá entender.

A terceira dica é selecionar bem o periódico dadas as características do manuscrito. A maioria dos periódicos tem uma missão indicando o tipo de artigos mais adequado. Adicionalmente, vários periódicos dão indicação aos revisores de itens específicos que precisam analisar nas suas avaliações e disponibilizam estes critérios nas suas páginas de internet. Por exemplo, a American Psychological Association (2001, p. 6) proporciona uma checklist com um conjunto de itens que os autores podem (devem) analisar para decidir se o seu manuscrito merece publicação (tradução minha com adaptações):

- A questão de pesquisa é relevante e o trabalho é original e importante?

- Os instrumentos usados têm fiabilidade e validade satisfatória?

- As medidas usadas são claramente relacionadas com as variáveis que a pesquisa pretende analisar?

- A concepção do artigo permite realmente testar as hipóteses?

- A amostra é representativa da população a que as generalizações se referem?

- O pesquisador seguiu os padrões éticos...?

- A pesquisa está num estádio de desenvolvimento que permita a publicação de resultados significativos?

Em Administração, pode ver um conjunto de recursos, incluindo os critérios, para os periódicos da Academy of Management Review (http://aom.org/Publications/AMr/Reviewer-

Resources.aspx) $\mathrm{e}$

Journal (http://aom.org/Publications/AMJ/Reviewer-

Resources.aspx). No Brasil, a ANPAD tem inclusive um manual de "Boas práticas da publicação científica: Um manual para autores, revisores, editores $e$ integrantes de corpos editoriais ${ }^{1 "}$, aprovado em 2010. $\mathrm{Na}$ RIAE, por exemplo, o formulário de avaliação 
questiona, numa escala tipo likert, sobre os seguintes aspectos:

- O artigo trata de elementos teóricos ou empíricos da área de Estratégia?

- O artigo apresenta novidade ou relevância científica (tema, teoria, método, resultado)?

- O título, o Resumo/Abstract e as palavraschave representam uma boa ideia do artigo como um todo?

- O artigo tem qualidade no desenvolvimento conceitual ou teórico?

- A revisão de literatura tem qualidade?

- O artigo tem rigor metodológico?

- O artigo está bem escrito e é claro?

Em seguida, em campos para escrita livre, pede uma avaliação para cada uma das seções principais do manuscrito:

- Introdução e problematização. Faça uma avaliação sobre a introdução, a problematização e o objeto do trabalho.

- Referencial teórico. Avalie se é contemplado o estado-da-arte sobre o assunto e se são utilizadas obras relevantes sobre o tema.

- Métodos e técnicas de pesquisa. Avalie se os métodos e as técnicas de pesquisa utilizados permitiram a obtenção de resultados consistentes.

- Análise dos dados e discussão dos resultados. Comente se há consistência na análise dos dados e se a discussão dos resultados é adequada.

- Conclusão ou considerações finais. Comente se a conclusão ou considerações finais são coerentes com o problema e o objetivo propostos, assim como elas contemplam as diversas partes do artigo.

valiação geral. Aponte no espaço abaixo sugestões aos autores para melhoria do artigo quanto a: (a) Conteúdo (resumo, desenvolvimento, interpretação, métodos e conclusões); (b) Forma (estrutura, linguagem, legibilidade); (c) Comentários adicionais ao autor (concentre-se resumidamente nos pontos fortes e fracos observados nos tópicos anteriores).

Em suma, utilize o seguinte acrónimo quando escrever o seu artigo:

Apresentação é fundamental

Considere os comentários e sugestões dos revisores

Examine criticamente o seu trabalho

Ineditismo - o artigo deve ser original e não publicado antes
Tome o seu tempo com a revisão (a revisão, reescrita, reescrita demora tempo)

Adira às normas éticas

Cuidadamente avalie a qualidade da escrita

A questão de pesquisa deve ser claramente expressa

Observe a contribuição do artigo

\section{REAGIR COM HUMOR OU INDIGNAÇÃO À REJEIÇÃO}

Na sequência de uma rejeição, alguns autores sentem a necessidade de expressar o seu descontentamento com o processo, ou os pareceres, e enviam cartas ao Editores. Penso que é mais sensato não o fazer e deixar passar o momento inicial de frustração para, mais claramente, analisar os benefícios dessa ação. Como já referi acima, usualmente há motivos válidos que presidiram à rejeição, ainda que não duvido que a subjetividade do processo, ou uma escolha menos óptima do revisor, possa ter conduzido ao desfecho.

Transcrevo em seguida duas cartas de resposta "bem-humoradas".

I shall skip the usual point-by-point description of every single change we made in response to the critiques. After all, it is fairly clear that your anonymous reviewers are less interested in the details of scientific procedure than in working out their personality problems and sexual frustrations by seeking some kind of demented glee in the sadistic and arbitrary exercise of tyrannical power over hapless authors like ourselves who happen to fall into their clutches. We do understand that, in view of the misanthropic psychopaths you have on your editorial board, you need to keep sending them papers, for if they weren 't reviewing manuscripts they'd probably be out mugging old ladies or clubbing baby seals to death.

(Baumeister 1992, p915).

\section{Dear Editors,}

Thank you for the rejection of our paper. As you know we receive a great many rejections, and unfortunately it is not possible for us to accept all of them. Your rejection was carefully reviewed by three experts in our laboratory, and based on their opinions, we find that it is not possible for us to accept your rejection. By this we do not imply any lack of esteem for you or your journal, and we hope that you will not hesitate to reject our papers in the future.

Yours sincerely,

Professor Hedgehog

(Mole, 2007, p. 1313) 


\section{REAGIR}

O sistema de avaliação que é expresso no "publish or perish", em que os Professores têm requisitos de publicação em periódicos de topo, é altamente estressante. A rejeição dos seus manuscritos significa para muitos académicos que não cumprirão os requisitos e não terão tenure (estabilidade no emprego na universidade). Em muitas universidades os professores que falham a tenure terão de procurar nova colocação. O sentimento de frustração pode, assim, tomar conta, como expressa a carta anônima que reproduzo em seguida.

After 11 straight rejections I think I am done. I have been submitting papers to peer-reviewed journals since May 2009 and until today nothing has worked out. My tenure is now in serious danger. The point is that I do not want to fool myself any further, the brutal truth is that I am just not good enough. It is normal to find excuses, to complain about the peer-review system, but probably it is just me.

The reviewers do not know who I am and they are expects; if my papers were truly good some should have been accepted for publication. The reality is that 11 different people, who are professionals, believe that I am not good enough, why should they be wrong? I think it is that more plausible that I am wrong.

I am starting to think that my past has been a lie. The admission to a very prestigious PhD program, the positive remarks of my PhD examiners. I think that I have been probably very lucky until now. Probably I simply met nice people who wrongly believed that I was good, while in fact I am not.

My school career proves my point. I have been a very strange student. Some teachers thought I was very good, some that I was very bad. I experienced getting the highest and the lowest grades. My results had nothing to do with my effort, I has always been very studious. In the past I believed that the teachers who did not value me were fool, maybe I was the fool.

There was a time in which I thought that the system was unfair; I questioned the validity of peerreviews and of the tenure-track system. Now I am ready to be honest: I was deluding myself. The tenuretrack system is just there to make sure that people who seem to be good but cannot deliver, like myself, are kicked out.

I have no alibi. My institution gave me enough time to work on my research. It is true that in my institution I have no one to share my work with, but it is also true that at this stage of my career I should be able to take care of myself.

There is something very very sad about all of this. I am a very hard-working and honest person. I work as hard as I can and put all of myself into what I do. Nonetheless, it is not enough. Getting published is not about how hard you work, it is about how clever and original you are.
I still have 2 years before I am up for tenure and to be honest what scares me the most is my determination and persistence. I know that I am a very strong willed person, but here is the problem: is persistence always a virtue? What if we delude ourselves that we can do something when we just cannot? We can try all our life to walk through a wall, but we will never succeed. I think that may be persistence is sometimes a form of dishonesty. In my case, I feel that I cannot accept being a mediocre scholar and will keep trying to prove others wrong. In the process I will kill myself with work, worries, and anger and then...I may still fail. I am sure you read stories about people who failed countless times but succeeded in the end. But what if it is also true that some people destroy themselves in trying and nothing is achieved. I read many times that failure is the key to success. Is that true? I know very brilliant people in my field who very rarely fail. I know stories of great athletes who knew only victories. Why should struggle be part of success?

My struggle now is to reach the point is which I am truly totally honest. I am not looking to a strategic way to consider my situation, I only want the truth. A part of me still hopes that may be I am good enough. This part scares me; I feel this part is the voice of my delusion and dishonesty. I feel that this voice is the voice of arrogance, the arrogance of a person who refuses to see his limitation and to say: I am not good.

Fonte:

http://morganonscience.com/grantwriting/the-grantrejection-letter/

\section{NOTAS FINAIS}

A rejeição do manuscrito que submete a um periódico é o resultado mais provável - avaliando a probabilidade como a frequência com que ocorre (Ehara \& Takahashi, 2007; Diniz, 2013). No entanto, a rejeição, apesar da subjetividade envolvida no processo de revisão pelos pares (peer review), não é um resultado absolutamente aleatório. As falhas nos manuscritos que tendem a conduzir à rejeição agrupam-se em redor de alguns fatores mais frequentemente observados. Entre as causas para a rejeição estão uma escrita e organização deficiente, falhas na concepção do estudo, falhas metodológicas (de mensuração, nas variáveis, dados insuficientes), insuficiente especificação da questão de pesquisa, ausência de contribuição - teoria e resultados triviais, conclusões não suportadas pelos dados e resultados, (Kassirer \& Campion, 1994; Byrne, 2000; Fiske \& Fogg, 1990; Ehara \& Takahashi, 2007).

Em resumo, os autores podem aumentar a probabilidade de terem os seus artigos aceites para publicação se seguirem alguns cuidados, nomeadamente planejando melhor as suas pesquisas antes de as iniciar, prestar mais cuidado aos métodos, passar mais tempo na revisão do texto e na formulação 
de qual a contribuição do seu artigo. Conhecer as causas de rejeição, pelo menos as mais frequentes, pode ajudar os autores a melhorar a qualidade dos seus trabalhos e a evitar as inevitáveis frustrações de ter um artigo rejeitado.

\section{Nota$$
1
$$$$
\text { Acessível }
$$

em

http://www.anpad.org.br/diversos/informativo/boas_pr aticas.pdf

\section{REFERÊNCIAS}

American Psychological Association. (2001). Publication manual of the American Psychological Association, $5^{\text {th }}$ ed., Washington, D.C.: American Psychological Association.

Baumeister, R. (1992). Dear Journal Editor, it's me again, American Journal of Roentgenology, 158, p. 915.

Booth, W., Colomb, G. \& Williams, J. (2008). The craft of research, $3^{\mathrm{a}}$ ed., University of Chicago Press.

Byrne, D. (2000). Common reasons for rejecting manuscripts at medical journals: A survey of editors and peer reviewers, Science Editor, 23(2): 39-44.
Casadevall, A. \& Fang, F. (2009). Is peer review censorship?, Infection and Immunity, 77(4): 12731274.

Diniz, E. (2013). Editorial, Revista de Administração de Empresas, 53(1): 1-2.

Eden, L. (2009). Letters from the Editor-in-Chief: JIBS status report - the first 18 months. Journal of International Business Studies, 40(5): 713-718.

Ehara, S. \& Takahashi, K. (2007). Reasons for rejection of manuscripts submitted to $A J R$ by international authors, American Journal of Radiology, 188: W113-W116.

Fiske, D. \& Fogg, L. (1990). But the reviewers are making different criticisms of my paper. American Psychologist, 45: 591-598.

Huff, A. (1999). Writing for scholarly publication. $1^{\mathrm{a}}$ ed., Thousand Oaks, CA: Sage.

Kassirer, J. \& Campion, E. (1994). Peer review: crude and understudied, but indispensable. Journal of the American Medical Association, 272: 96-97.

Krueger, T. \& Shorter, J. (2011). Variation in scholarly journal review processes and acceptance rates across time and disciplines, Southwestern Business Administration Journal, 11(2): 71-112.

Mole. (2007). Rebuffs and rebuttals II: take me back!, Journal of Cell Science, 120(8): 1311-1313 